\title{
Rapid growth in nitrogen dioxide pollution over Western China, 2005-2013
}

\author{
Yuanzheng Cui ${ }^{1}$, Jintai Lin ${ }^{2}$, Chunqiao Song ${ }^{3}$, Mengyao Liu ${ }^{2}$, Yingying Yan ${ }^{2}$, Yuan Xu ${ }^{1}$, and Bo Huang ${ }^{1,4}$ \\ ${ }^{1}$ Department of Geography and Resource Management, The Chinese University of Hong Kong, Shatin, Hong Kong, China \\ ${ }^{2}$ Laboratory for Climate and Ocean-Atmosphere Studies, Department of Atmospheric and Oceanic Sciences, \\ School of Physics, Peking University, Beijing 100871, China \\ ${ }^{3}$ Department of Geography, University of California, Los Angeles, Portola Plaza, Los Angeles, CA 90095, USA \\ ${ }^{4}$ Institute of Space and Earth Information Science, The Chinese University of Hong Kong, Shatin, Hong Kong, China
}

Correspondence to: Jintai Lin (linjt@pku.edu.cn) and Bo Huang (bohuang@cuhk.edu.hk)

Received: 7 November 2015 - Published in Atmos. Chem. Phys. Discuss.: 14 December 2015

Revised: 25 March 2016 - Accepted: 4 May 2016 - Published: 20 May 2016

\begin{abstract}
Western China has experienced rapid industrialization and urbanization since the implementation of the National Western Development Strategies (the "Go West" movement) in 1999. This transition has affected the spatial and temporal characteristics of nitrogen dioxide $\left(\mathrm{NO}_{2}\right)$ pollution. In this study, we analyze the trends and variability of tropospheric $\mathrm{NO}_{2}$ vertical column densities (VCDs) from 2005 to 2013 over Western China, based on a wavelet analysis on monthly mean $\mathrm{NO}_{2}$ data derived from the Ozone Monitoring Instrument (OMI) measurements. We focus on the anthropogenic $\mathrm{NO}_{2}$ by subtracting region-specific "background" values dominated by natural sources. After removing the background influences, we find significant anthropogenic $\mathrm{NO}_{2}$ growth over Western China between 2005 and $2013\left(8.6 \pm 0.9 \% \mathrm{yr}^{-1}\right.$ on average, relative to 2005$)$, with the largest increments $\left(15 \% \mathrm{yr}^{-1}\right.$ or more) over parts of several city clusters. The $\mathrm{NO}_{2}$ pollution in most provinciallevel regions rose rapidly from 2005 to 2011 but stabilized or declined afterwards. The $\mathrm{NO}_{2}$ trends were driven mainly by changes in anthropogenic emissions, as confirmed by a nested GEOS-Chem model simulation and a comparison with Chinese official emission statistics. The rate of $\mathrm{NO}_{2}$ growth during 2005-2013 reaches $11.3 \pm 1.0 \% \mathrm{yr}^{-1}$ over Northwestern China, exceeding the rates over Southwestern China $\left(5.9 \pm 0.6 \% \mathrm{yr}^{-1}\right)$ and the three well-known polluted regions in the east $\left(5.3 \pm 0.8 \% \mathrm{yr}^{-1}\right.$ over Beijing-TianjinHebei, $4.0 \pm 0.6 \% \mathrm{yr}^{-1}$ over the Yangtze River Delta, and $-3.3 \pm 0.3 \% \mathrm{yr}^{-1}$ over the Pearl River Delta). Subsequent socioeconomic analyses suggest that the rapid $\mathrm{NO}_{2}$ growth
\end{abstract}

over Northwestern China is likely related to the fast developing resource- and pollution-intensive industries along with the "Go West" movement as well as relatively weak emission controls. Further efforts should be made to alleviate $\mathrm{NO}_{x}$ pollution to achieve sustainable development in Western China.

\section{Introduction}

Nitrogen oxides $\left(\mathrm{NO}_{x}=\mathrm{NO}+\mathrm{NO}_{2}\right)$ are major constituents in tropospheric chemistry, leading to ozone formation, acid deposition, and particulate matter pollution. $\mathrm{NO}_{x}$ are emitted into the troposphere from anthropogenic activities (thermal power plants, transportation, industries, and residential use) and natural sources (lightning, open fires, and soil) (Lin, 2012; Russell et al., 2012). Rapid economic development and urbanization across China in recent decades have caused serious air pollution problems, with $\mathrm{NO}_{x}$ becoming the fastest growing air pollutant in China over the last 2 decades (Richter et al., 2005; Zhang et al., 2012; Zhao et al., 2013).

Vertical column densities (VCDs) of tropospheric $\mathrm{NO}_{2}$ retrieved from various satellite instruments have been used widely to study $\mathrm{NO}_{x}$ pollution over China (Richter et al., 2005; van der A et al., 2006; He et al., 2007; Wang et al., 2007b; X. Zhang et al., 2007; Zhang et al., 2012; Gu et al., 2013; Huang et al., 2013; Lin et al., 2014b). Satellite observations provide a tool to infer patterns of anthropogenic and natural $\mathrm{NO}_{x}$ emissions (Q. Zhang et al., 2007; Stavrakou et 
al., 2008; van der A et al., 2008; Zhang et al., 2009b; Zhao and Wang, 2009; Li et al., 2010; Lin et al., 2010b; Lamsal et al., 2011; Lin, 2012; Wang et al., 2012; Reuter et al., 2014; Lin et al., 2015). They are also useful to analyze the large variations in $\mathrm{NO}_{x}$ pollution during several short-term socioeconomic events, such as the Sino-African summit, Beijing Olympic Games, Shanghai Expo, Guangzhou Asian Games, Chinese economic recession and Chinese New Year (Wang et al., 2007a; Mijling et al., 2009; Wang et al., 2009; Witte et al., 2009; Hao et al., 2011; Lin and McElroy, 2011; Lin et al., 2013).

Most of prior studies have focused on Eastern China, with little attention paid to Western China. As shown in Fig. 1, Western China is specified here as the vast region covering six provinces (Gansu, Guizhou, Qinghai, Shaanxi, Sichuan and Yunnan), five provincial-level autonomous regions (Guangxi, Inner Mongolia, Ningxia, Tibet and Xinjiang), and one provincial-level municipality (Chongqing City). Western China has experienced significant socioeconomic changes following the National Western Development Strategies (the "Go West" movement) launched by the Chinese government in 1999. Over the last decade, the rates of industrialization and urbanization in Western China has accelerated (Deng and Bai, 2014). Western China is rich in natural resources, such as water, coal, natural gas, petroleum, and minerals. With the adjustment of regional development strategy at a national level, those energy-intensive industries formerly located in Eastern China have been encouraged to move westward (Zhao et al., 2015), although the ecosystems of Western China may be more fragile than those of Eastern China (Shao and Qi, 2008; Chen et al., 2010; Bai et al., 2014; Zhao et al., 2015). Although the "Go West" movement is beneficial for local industrial and economic development in Western China, it may have led to unintended environmental impacts that have yet to be understood. The short lifetime of tropospheric $\mathrm{NO}_{2}$ (hours to a day), its strong link and rapid response to emissions, and the availability of high-quality satellite measurements allow evaluating pollution changes and the possibility of sustainable development in Western China. Satellite measurements are particularly important when sufficient ground-based measurements are lacking.

This study investigates the spatiotemporal variations of tropospheric $\mathrm{NO}_{2}$ VCDs between October 2004 and May 2014 over Western China and potential human influences, by analyzing the monthly Royal Netherlands Meteorological Institute (KNMI) Ozone Monitoring Instrument (OMI) $\mathrm{NO}_{2}$ data (DOMINO v2). We apply a wavelet decomposition analysis to reveal the long-term trends of tropospheric $\mathrm{NO}_{2}$ over Western China. We also use a nested GEOS-Chem simulation and Chinese official emission statistics to confirm that anthropogenic emissions are the main driver of $\mathrm{NO}_{2}$ variations. At last, we discuss the regional differences in $\mathrm{NO}_{2}$ growths between Northwestern and Southwestern China and between Western and Eastern China, and we associate these differences with the driving socioeconomic factors of individual regions.

\section{Data and study area}

\subsection{Satellite data}

OMI is onboard the EOS-Aura satellite. The satellite measurements have a pixel size of $13 \times 24 \mathrm{~km}^{2}$ at nadir with a local overpass time around 13:40. VCDs of tropospheric $\mathrm{NO}_{2}$ are derived in three major steps, including derivation of slant column densities (SCDs), separation of stratospheric and tropospheric SCDs, and calculation of tropospheric air mass factors (AMFs) for deduction of the tropospheric VCDs. On a regional and monthly mean basis, the error of retrieved VCDs is about $30 \%$ (a relative error) plus $0.7 \times 10^{15}$ molecules $\mathrm{cm}^{-2}$ (an absolute error) (Boersma et al., 2011; Lin and McElroy, 2011). More detailed algorithms and error descriptions involved in retrieving tropospheric $\mathrm{NO}_{2}$ VCDs can be found in Boersma et al. (2007, 2011).

We mapped the level-2 DOMINO v2 product (http://www. temis.nl/airpollution/no2.html, Boersma et al., 2015) to a $0.25^{\circ} \times 0.25^{\circ}$ grid, and then averaged daily data to produce monthly mean VCD values. We used data from October 2004 to May 2014 for the present analysis. For data quality control, we excluded pixels with a cloud radiance fraction $>50 \%$ or affected by row anomaly (Boersma et al., 2011). We filled the missing monthly mean values in some grid cells using values in the adjacent years; the impact on the trend analysis is found to be small by sensitivity analyses on the respective GEOS-Chem simulation results (see Sect. 4.2.2).

\subsection{GEOS-Chem Modeling}

We used the nested GEOS-Chem chemical transport model version $9-02$, on a $0.667^{\circ}$ long. $\times 0.5^{\circ}$ lat. grid with 47 vertical layers, to simulate the tropospheric $\mathrm{NO}_{2}$ and other pollutants over Asia (Chen et al., 2009). The model is run with the full $\mathrm{O}_{x}-\mathrm{NO}_{x}-\mathrm{VOC}-\mathrm{CO}-\mathrm{HO}_{x}$ gaseous chemistry and online aerosol calculations, and it is driven by the GEOS- 5 assimilated meteorology from the NASA Global Modeling and Assimilation Office. Vertical mixing in the planetary boundary layer follows the non-local parameterization scheme implemented by Lin et al. (2010b). Convection is simulated with a modified Relaxed Arakawa-Schubert scheme (Rienecker et al., 2008). Lateral boundary conditions of the nested model are updated every $3 \mathrm{~h}$ by results from corresponding global modeling on a $5^{\circ}$ long. $\times 4^{\circ}$ lat. grid.

Chinese anthropogenic emissions of $\mathrm{NO}_{x}$ and other species adopt the monthly MEIC inventory with a base year of 2008 (www.meicmodel.org). The spatial resolution of MEIC used in the simulation is $0.667^{\circ}$ long. $\times 0.5^{\circ}$ lat., according to the model grid. We further scaled monthly anthropogenic $\mathrm{NO}_{x}$ emissions to other years, by applying the ratios 


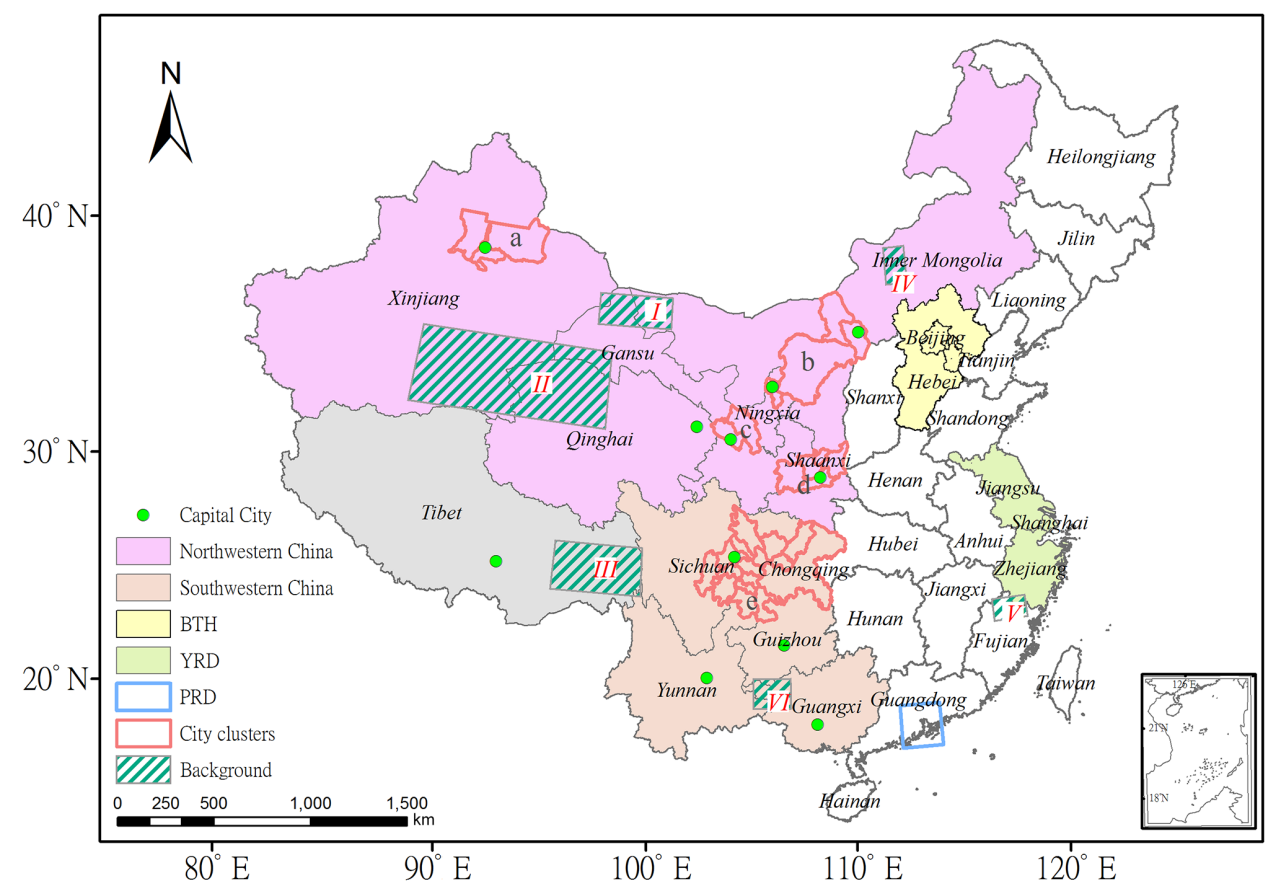

Figure 1. The study regions. Several city clusters are also identified: (a) Urumqi city cluster, (b) Inner Mongolia industrial city cluster, (c) Gansu-Ningxia, (d) Shaanxi-Guanzhong, and (e) Chengdu-Chongqing.

of monthly DOMINO v2 $\mathrm{NO}_{2} \mathrm{VCDs}$ in those years over the VCDs in the respective months of 2008. The scaling with OMI data was done at the model resolution, after regridding the satellite data from the $0.25^{\circ}$ long. $\times 0.25^{\circ}$ lat. resolution. Emissions for other Asian regions follow the INTEX-B inventory (Zhang et al., 2009a). Other model setups are described in Lin et al. (2015).

Due to limited meteorological inputs, model simulations were conducted from 2004 to April 2013. The first simulation year was used for model spin-up, and results from 2005 onward were analyzed in the present analysis. In the following order, modeled vertical profiles of $\mathrm{NO}_{2}$ were averaged over 13:00-15:00 local time, regridded to a $0.25^{\circ} \times 0.25^{\circ}$ grid, sampled in locations and days with valid OMI data, applied with the DOMINO averaging kernel (AK), and then averaged to derive monthly mean VCD values. The use of AK was to eliminate the effect of differences in $\mathrm{NO}_{2}$ vertical profiles between GEOS-Chem and TM4 (that provides the a priori profiles for the DOMINO retrieval). Following our previous work (Lin et al., 2010a; Lin, 2012), we regridded the pixelspecific AK to the $0.25^{\circ} \times 0.25^{\circ}$ grid. Modeled VCDs data without applying the $\mathrm{AK}$ are also analyzed in Sect. 4.2.2 to test the effects of data sampling and temporal interpolation.

\subsection{Official anthropogenic emission and socioeconomic data}

We took Chinese official provincial-level $\mathrm{NO}_{x}$ emission inventories for 2007 and 2010-2013 to compare with trends in
$\mathrm{OMI} \mathrm{NO}$. Chinese central government commenced its official estimate of anthropogenic $\mathrm{NO}_{x}$ emissions following the first nationwide pollution census in 2007. (The first nationwide pollution census committee, 2011). $\mathrm{NO}_{x}$ emissions in 2010-2013 were also based on the estimating system of the first pollution census, allowing for a consistent comparison throughout time. We also included the official emission targets aimed for 2015 from the 12th Five-Year Plan (20112015), a well-known socioeconomic planning step of China. We obtained all socioeconomic data from the China Statistical Yearbooks Database (http://tongji.cnki.net/overseas/ engnavi/navidefault.aspx).

\subsection{Study area}

Figure 1 highlights the study area in China. We extracted provincial and regional $\mathrm{NO}_{2}$ data according to their administrative divisions. We separated Western China into two subregions, including Northwestern China (Gansu, Inner Mongolia, Ningxia, Qinghai, Shaanxi and Xinjiang) and Southwestern China (Chongqing, Guangxi, Guizhou, Sichuan and Yunnan). Tibet is excluded from the present analysis due to lack of socioeconomic data. We also selected three key regions from Eastern China for comparisons with Western China: the Beijing-Tianjin-Hebei region (BTH, including Beijing, Tianjin and Hebei Province), the Yangtze River Delta (YRD, including Shanghai, Jiangsu Province and Zhejiang Province) and the Pearl River Delta (PRD, part of Guangdong Province). 


\section{Methods}

\subsection{Determining areas dominated by anthropogenic $\mathrm{NO}_{2}$}

This study is focused on areas that have been subjected to significant changes in anthropogenic $\mathrm{NO}_{x}$ emissions. Since $\mathrm{NO}_{x}$ are emitted from both anthropogenic and natural sources (Lin, 2012), we exploited their distinctive seasonal patterns to determine areas dominated by anthropogenic sources.

Over China, anthropogenic emissions tend to maximize in winter, although the seasonal variation is often within $20 \%$ (Zhang et al., 2009a). Soil and lightning emissions exhibit summer maxima with very low values in winter. Biomass burning emissions of $\mathrm{NO}_{x}$ are negligible over China (Lin, 2012). In addition, the lifetime of $\mathrm{NO}_{x}$ in winter is several times longer than in summer. Therefore the $\mathrm{NO}_{2} \mathrm{VCDs}$ are the lowest in summer and the highest in winter over the areas dominated by anthropogenic sources, while the opposite seasonality occurs over the regions dominated by natural emissions (Lin, 2012). Furthermore, lightning and soil emissions are mostly independent of direct anthropogenic influences for 2005-2013, albeit with certain effects from changes in climate and/or land use. There is no evidence that these natural emissions underwent significant trends from 2005 to 2013. By comparison, anthropogenic emissions have exhibited dramatic changes along with the rapid socioeconomic development, and these changes have affected the seasonality of $\mathrm{NO}_{2}$.

Figure $2 \mathrm{a}$ shows the seasonal variation in $\mathrm{OMI} \mathrm{NO}_{2}$ VCDs, averaged over $2005-2013$, for each $0.25^{\circ} \times 0.25^{\circ}$ grid cell in Western China; all grid cells are sorted according to their 9-year mean $\mathrm{NO}_{2}$ values. Once a grid cell is ordered, its monthly $\mathrm{NO}_{2}$ values are averaged over 20052013 to obtain a 9-year mean monthly climatological data set with 12 values. Finally, the monthly climatological values are converted to their reverse ranks (from 1 to 12 ), for improved illustration across all grid cells. Figure 2a shows that for grid cells with 9-year mean $\mathrm{NO}_{2} \mathrm{VCDs}$ below $1.0 \times 10^{15}$ molecules $\mathrm{cm}^{-2}, \mathrm{NO}_{2}$ generally experiences summer maxima and winter minima, reflecting the dominance of natural sources. In contrast, grid cells with 9-year mean $\mathrm{NO}_{2}$ VCDs above $1.0 \times 10^{15}$ molecules $\mathrm{cm}^{-2}$ exhibit winter maxima, due to the dominance of anthropogenic emissions as well as a longer lifetime. Van der A et al. (2006) also found that over 1996-2005, polluted Eastern China experienced $\mathrm{NO}_{2}$ maxima in winter due to large anthropogenic emissions while much cleaner western China experienced summer maxima due to natural sources. Similar results were shown by Lin (2012) who compared polluted and cleaner regions in Eastern China in 2006.

Figure $2 \mathrm{~b}$ further shows the standard deviation (SD) of monthly OMI $\mathrm{NO}_{2}$ VCDs year by year for each $0.25^{\circ} \times 0.25^{\circ}$ grid cell in Western China; again, all grid cells are sorted according to their 9-year mean $\mathrm{NO}_{2}$ values. Once a grid cell is ordered, the SD is calculated for each year to obtain a data set with nine values over 2005-2013. Finally, the SD values are converted to their reverse ranks (from 1 to 9), for better illustration across all grid cells. Figure $2 \mathrm{~b}$ shows that grid cells with 9-year mean $\mathrm{NO}_{2} \mathrm{VCDs}$ above $1.0 \times 10^{15}$ molecules $\mathrm{cm}^{-2}$ exhibit a large growth in SD especially since 2009, as a result of large growth in anthropogenic emissions that amplified the seasonality. By comparison, grid cells with 9-year mean $\mathrm{NO}_{2} \mathrm{VCDs}$ below $1.0 \times 10^{15}$ molecules $\mathrm{cm}^{-2}$ did not experience such significant changes in SD between 2005 and 2013.

Based on the above seasonality analysis, we determined the regions dominated by anthropogenic emissions as those with 2005-2013 mean $\mathrm{NO}_{2}$ VCDs exceeding $1.0 \times 10^{15}$ molecules $\mathrm{cm}^{-2}$.

\subsection{Removing contributions from natural sources}

To obtain the sole anthropogenic $\mathrm{NO}_{2}$, we further subtracted all $\mathrm{NO}_{2}$ VCDs by certain "background" values representing the natural influences. Removing the "background" influences is meaningful for Western China where the $\mathrm{NO}_{2} \mathrm{VCDs}$ are currently not at an extremely high level (see Sect. 4.2.1).

We identified six "background" areas that are away from cities and are supposed to be dominated by natural emissions (see the hatched areas in Fig. 1), and we assumed $\mathrm{NO}_{2}$ VCDs there are all natural. Russell et al. (2012) used the same method to identify "background" $\mathrm{NO}_{2}$ over the United States. When calculating the trends of $\mathrm{NO}_{2}$ in the grid cells of the chosen human-dominant areas, we subtracted $\mathrm{NO}_{2} \mathrm{VCDs}$ at these grid cells by the $\mathrm{NO}_{2}$ value averaged over the nearest "background" region. For all grid cells in a given province, the corresponding background region is the same and is indicated in Table 1. The background subtraction was done on a monthly basis to account for natural variability. We processed the model $\mathrm{NO}_{2}$ data with the same method.

Figure 1 shows that the "background" regions in Western China are normally the uninhabited areas. Over there, the $\mathrm{NO}_{2}$ VCDs are only about $0.4-0.5 \times 10^{15}$ molecules $\mathrm{cm}^{-2}$ in 2005 (with little interannual variability), lower than $\mathrm{NO}_{2}$ in the polluted areas by a factor of 2-5 (Table 1). For Eastern China (Table 1), the "background" values are higher (0.7 $1.2 \times 10^{15}$ molecules $\mathrm{cm}^{-2}$ in 2005); whereas these values are 6-13 times lower than the $\mathrm{NO}_{2} \mathrm{VCDs}$ over the three polluted eastern regions (BTH, YRD and PRD).

Note that the chosen "background" values may not fully represent the actual natural contributions to the targeted human-dominant areas. For example, soil emissions may vary in space due to differences in temperature, radiation, land cover and land use type, and other climatic factors. Lightning emissions of $\mathrm{NO}_{x}$ may have spatial dependence as well. The "background" regions may not be totally free from anthropogenic influences, as a certain amount of $\mathrm{NO}_{x}$ in the polluted areas may be oxidized to produce peroxyacyl ni- 

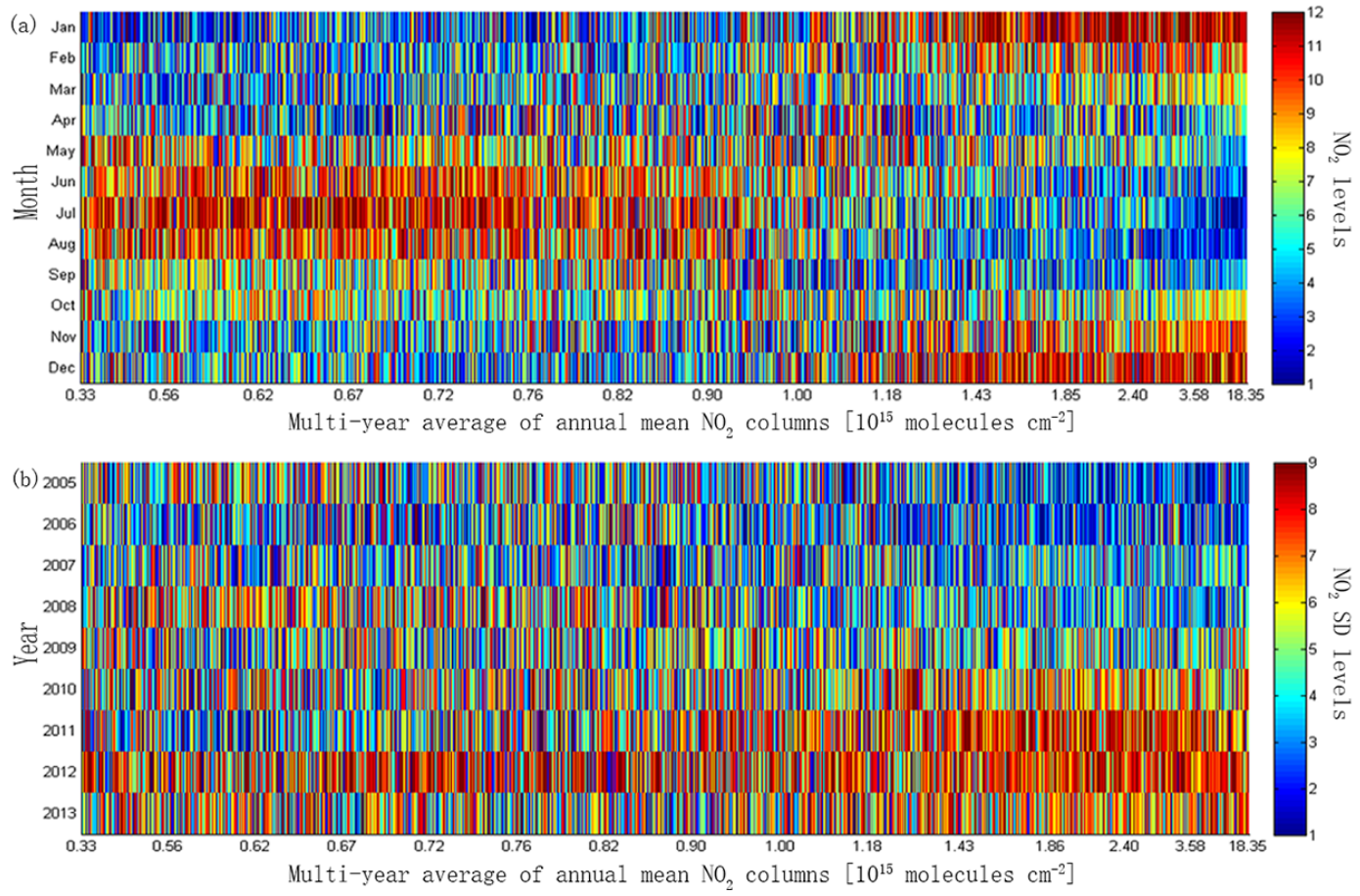

Figure 2. (a) 2005-2013 average seasonal variation of $\mathrm{OMI} \mathrm{NO} 2 \mathrm{VCDs}_{\text {for each }} 0.25^{\circ} \times 0.25^{\circ}$ grid cell of Western China; the grid cells are sorted by their 9-year average $\mathrm{NO}_{2}$ VCDs. For each grid cell, the 9-year average monthly $\mathrm{NO}_{2}$ values are converted to their reverse

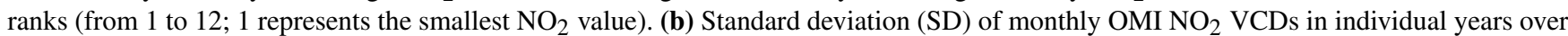
2005-2013 for each $0.25^{\circ} \times 0.25^{\circ}$ grid cell of Western China; the grid cells are sorted by their 9-year average $\mathrm{NO}_{2} \mathrm{VCDs}_{\text {. For each grid }}$ cell, the seasonal SDs in the 9 years are converted to their reverse ranks (from 1 to $9 ; 1$ represents the smallest SD value).

trates (PANs), which can be transported to "background" areas and converted back to $\mathrm{NO}_{x}$. For these reasons, our choice of background values is relatively rough. Nevertheless, unless the actual natural contributions differ substantially from the chosen values, which we do not expect to occur on a provincial average, the resulting effect on our trend calculations should be small, because the chosen background values are smaller than $\mathrm{NO}_{2}$ over their corresponding polluted areas by a factor of 2-13 (Table 1). Future work is needed to fully separate the anthropogenic from natural $\mathrm{NO}_{2}$ for individual locations.

\subsection{Wavelet decomposition analysis}

Due in part to the short lifetime of $\mathrm{NO}_{x}$, the tropospheric $\mathrm{NO}_{2}$ VCDs respond quickly to emission changes at various temporal scales, from a general growth along with socioeconomic development to short-term perturbations such as the Chinese New Year holidays and the economic recession (Lin and McElroy, 2011; Lin et al., 2013). Also, uncertainties and sampling biases in the satellite data may introduce additional noises in the $\mathrm{NO}_{2}$ monthly time series. If not separated, these short-term variability and noises may affect linear trend calculations.

Here we conducted discrete wavelet transform (DWT) (Daubechies, 1992; Partal and Küçük, 2006) to distinguish temporal variability of $\mathrm{NO}_{2}$ at multiple scales. The wavelet transform is a useful tool for diagnosing the multi-scale and non-stationary processes over finite space and time periods, with the advantage of localization in the time and frequency domain (Echer, 2004; Percival and Walden, 2006), suitable for our analysis of $\mathrm{NO}_{2}$ trends and variability. Different from the approaches adopted by previous $\mathrm{NO}_{2}$ studies (e.g., van der A et al., 2006), our wavelet analysis does not require prior assumptions about seasonality and other temporal scales. As shown in Sect. 3.1, the magnitude of $\mathrm{NO}_{2}$ seasonality is correlated to the amount of annual mean $\mathrm{NO}_{2}$ and anthropogenic sources, and this information is captured by the wavelet analysis here.

The multi-scale analysis in DWT is able to decompose a time series $f(t)$ into $n$ scale components ( $n$ is the decomposition level):

$f(t)=\sum_{i=1}^{n} D_{i}+A_{n}$

where $D_{i}$ is a detail signal (high frequency) at level $i$ and $A_{n}$ is the approximation signal (low frequency) at the set of maximum level $n$. The detail and approximation signals were generated based on the convolution of time series of wavelet functions and scaling functions. We chose Meyer orthogonal discrete wavelets as the wavelet functions which 
Table 1. Regional trends of $\mathrm{OMI} \mathrm{NO}_{2}$ VCDs over 2005-2013 and $\mathrm{NO}_{x}$ emission reduction plan of 2015.

\begin{tabular}{|c|c|c|c|c|}
\hline & Region & $\begin{array}{r}\text { Average } \mathrm{NO}_{2} \text { in } 2005^{\mathrm{a}} \\
10^{15} \text { molecules } \mathrm{cm}^{-2}\end{array}$ & $\begin{array}{l}\mathrm{NO}_{2} \text { trend }^{\mathrm{b}} \\
\quad\left(\% \mathrm{yr}^{-1}\right)\end{array}$ & $\begin{array}{r}\mathrm{NO}_{x} \text { emission reduction } \\
\text { plan of } 2015(\%)^{\mathrm{c}}\end{array}$ \\
\hline \multirow{6}{*}{ Northwest } & Gansu & $0.9(0.4, \mathrm{I})$ & $7.5 \pm 1.2$ & 3.1 \\
\hline & Inner Mongolia & $1.1(0.4, \mathrm{I})$ & $10.2 \pm 1.3$ & 5.8 \\
\hline & Ningxia & $1.4(0.4, \mathrm{I})$ & $12.3 \pm 1.7$ & 4.9 \\
\hline & Qinghai & $1.0(0.5, \mathrm{II})$ & $11.2 \pm 1.2$ & -15.3 \\
\hline & Shaanxi & $2.3(0.5, \mathrm{II})$ & $10.5 \pm 1.0$ & 9.9 \\
\hline & Xinjiang & $1.0(0.5, \mathrm{II})$ & $15.1 \pm 2.0$ & 0 \\
\hline \multirow{5}{*}{ Southwest } & Chongqing & $2.2(0.5$, III $)$ & $7.8 \pm 0.9$ & 6.9 \\
\hline & Guangxi & $1.2(0.5, \mathrm{III})$ & $4.0 \pm 0.5$ & 8.8 \\
\hline & Guizhou & $1.3(0.5, \mathrm{III})$ & $6.9 \pm 1.0$ & 9.8 \\
\hline & Sichuan & $1.7(0.5, \mathrm{III})$ & $6.1 \pm 0.7$ & 6.9 \\
\hline & Yunnan & $0.7(0.5, \mathrm{III})$ & $4.2 \pm 0.3$ & 5.8 \\
\hline \multirow{6}{*}{ Region } & West & $1.3(0.5, \mathrm{II})$ & $8.6 \pm 0.9$ & 5.7 \\
\hline & Northwest & $1.2(0.5, \mathrm{II})$ & $11.3 \pm 1.0$ & 4.5 \\
\hline & Southwest & $1.4(0.5, \mathrm{III})$ & $5.9 \pm 0.6$ & 7.6 \\
\hline & ВTH & $9.2(0.7, \mathrm{IV})$ & $5.3 \pm 0.8$ & 13.9 \\
\hline & YRD & $7.2(1.2, \mathrm{~V})$ & $4.1 \pm 0.6$ & 17.7 \\
\hline & PRD & $8.0(1.2, \mathrm{VI})$ & $-3.3 \pm 0.3$ & 16.9 \\
\hline
\end{tabular}

have been used to study ozone column, NDVI and land-cover changes (Abry, 1997; Echer, 2004; Freitas and Shimabukuro, 2008; Martínez and Gilabert, 2009). Specifically, the approximation and detail signals were derived through an iterative multi-layer decomposition process. In the first layer of decomposition, $f(t)=A_{1}+D_{1}$. Then, $A_{1}=A_{2}+D_{2}$ and $f(t)=A_{2}+D_{2}+D_{1}$; and so on. The iteration stops at level $n=5$ for all provinces. At level 5 , the period of the $A_{5}$ time series is longer than the length of the data set (116 months). This criterion is typically used in investigating the long-term trend of a time series (Echer, 2004; Chen et al., 2014). As an example, Fig. 3 presents the wavelet transform result for one grid cell $\left(34.5^{\circ} \mathrm{N}, 108.9^{\circ} \mathrm{E}\right)$ in Xi' an City, Shaanxi Province.

As a result, the approximation signal $A_{5}$ represents the long-term trend of the original $\mathrm{NO}_{2}$ time series (with a period longer than the length of the data set). Although similar to the 12 -month moving average time series, the $A_{5}$ time series is much smoother with no short-term variability (see the example in Fig. 3). The detail components $D_{1}-D_{5}$ indicate higher-frequency variations, which are not analyzed in this study.

\section{Results and analysis}

\subsection{Spatial patterns of tropospheric $\mathrm{NO}_{2} \mathrm{VCDs}$ over China, prior to removing "background" influences}

Figure 4 shows the spatial distributions of annual average OMI NO $\mathrm{NO}_{2}$ VCDs over China in 2005, 2012 and 2013. Here the "background" values have not been subtracted. The $\mathrm{NO}_{2}$ VCDs exceed a high value of $6 \times 10^{15}$ molecules $\mathrm{cm}^{-2}$ in many areas of Central-East China and parts of Western China. Chengdu-Chongqing, Urumqi and ShaanxiGuanzhong city clusters are well-known pollution "hot spots" of Western China (see Fig. 1 for region definitions). These "hot spots" have intensified since 2005, as well as other polluted western areas including Gansu-Ningxia and Inner Mongolia industrial city clusters. The annual and regional average $\mathrm{NO}_{2} \mathrm{VCDs}$ over Western China has increased by $51 \%$ between 2005 and 2013, higher than the increase at $41 \%$ in Central-East China. The large growth of $\mathrm{NO}_{2}$ over Western China highlights the necessity of understanding potential human influences in these regions.

Figure 4 also compares the OMI derived and GEOS-Chem modeled annual average $\mathrm{NO}_{2}$ VCDs in 2005 and 2012. OMI and model $\mathrm{NO}_{2}$ share similar spatial and temporal patterns. Linear regression for model $\mathrm{NO}_{2}$ as a function of OMI $\mathrm{NO}_{2}$ reveals that for any given year, model $\mathrm{NO}_{2}$ are highly correlated with OMI values in space. Table 2 shows that for all of China in 2008, the magnitudes of model $\mathrm{NO}_{2}$ are close 


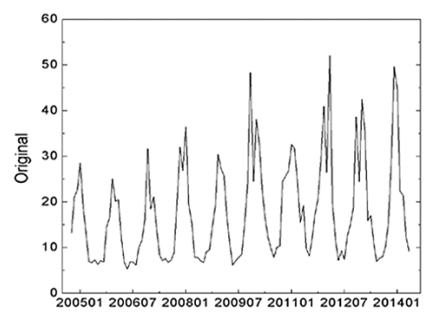

Time
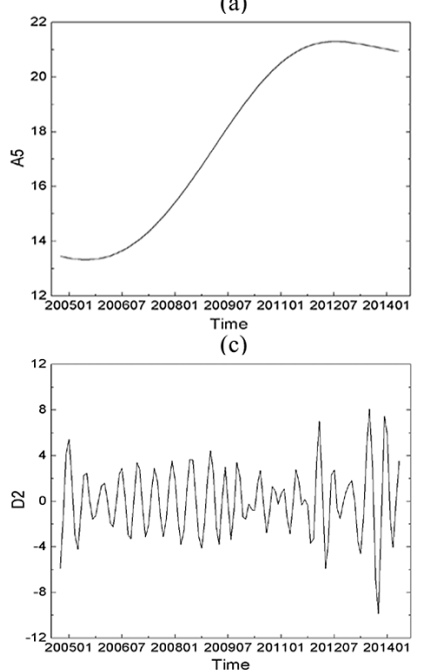

(e)

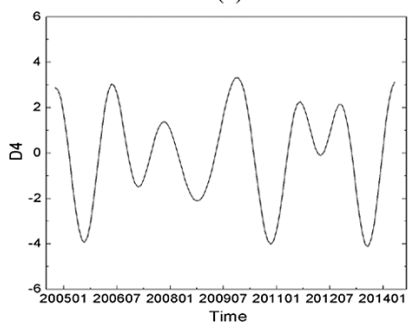

(g)

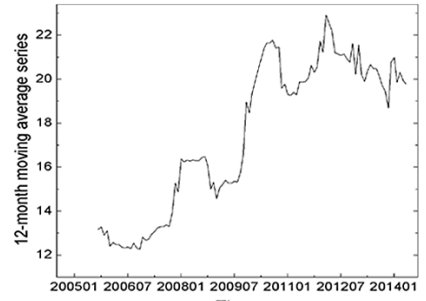

(b)

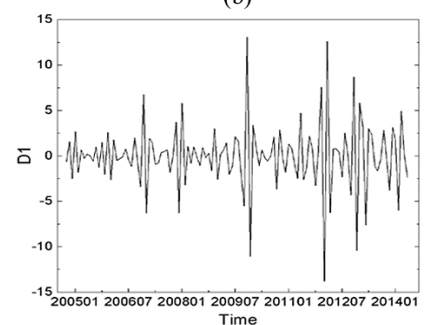

(d)

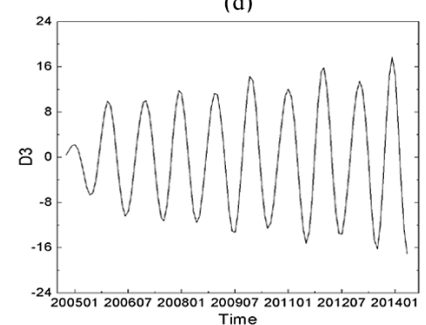

(f)

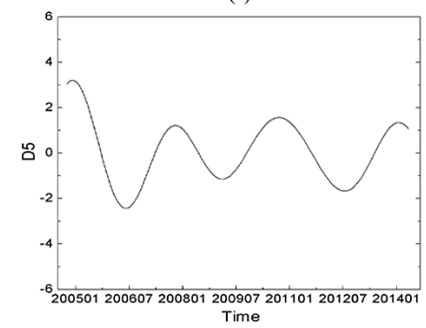

(h)
Figure 3. An example of the 5-level wavelet decomposition. (a) The original monthly time series of $\mathrm{OMI} \mathrm{NO}_{2}$ at a grid cell in Xi' an $\left(34.5^{\circ} \mathrm{N}, 108.9^{\circ} \mathrm{E}\right),(\mathrm{b})$ the 12 -month moving average time series, (c) the approximation signal $A_{5}$ representing the long-term trend, (d-h) five decomposition levels $D_{1}-D_{5}$ indicating temporal variability at various scales.

to $\mathrm{OMI} \mathrm{NO}_{2}$ (slope $=1.09, R^{2}=0.88$ ). For other years, the slopes are larger (1.11-1.26), indicating positive model biases, while the $R^{2}$ ranges from 0.86 to 0.90 . The scatterplot in Fig. 4 further confirms the model-OMI consistency in 2012. Similar results are found for Western China, although the $R^{2}$ is smaller, at $0.68-0.76$ over $2005-2012$. The model biases in years other than 2008 reflect the nonlinear relation between changes in $\mathrm{NO}_{x}$ emissions and changes in $\mathrm{NO}_{2}$ VCDs (Martin et al., 2003; Valin et al., 2011; Lin, 2012) that we did not account for when linearly scaling model emissions from MEIC 2008 to other years based on the interannual variation in $\mathrm{OMI} \mathrm{NO}_{2}$.

\subsection{Trends of anthropogenic $\mathrm{NO}_{2}$ over Western China, after removing "background" influences}

\subsection{1 $\mathrm{NO}_{2}$ trends}

Figure 5 shows $\mathrm{OMI}$ and modeled $\mathrm{NO}_{2}$ trends at individual grid cells over Western China, by applying a linear regression to the approximation signal $A_{5}$ from the wavelet decomposition. All trend values are normalized relative to the 2005 mean $\mathrm{NO}_{2}$ VCDs. All the $\mathrm{NO}_{2}$ data have been subtracted by its respective "background" values prior to the wavelet analysis. Results are only shown for grid cells with 2005-2013 average $\mathrm{NO}_{2}$ VCDs exceeding $1.0 \times 10^{15}$ molecules $\mathrm{cm}^{-2}$ and with statistically significant trends $(P$ value $<0.05$ according to an $F$ test). Note that the growth rates without subtracting "background" values are smaller than the rates with "background" values subtracted by $0.5-2.9 \% \mathrm{yr}^{-1}\left(1.5 \% \mathrm{yr}^{-1}\right.$ on average) over the northwestern provinces and $0.1-1.0 \% \mathrm{yr}^{-1}$ $\left(0.7 \% \mathrm{yr}^{-1}\right.$ on average) over the southwestern provinces. In addition, the $A_{5}$-based trends here are similar to the linear trends calculated based on the original $\mathrm{NO}_{2}$ time series (not shown). However, as the wavelet transform removes smallscale variability and noises, we believe the $A_{5}$-based trends are more robust in general.

Figure 5a shows that $\mathrm{OMI} \mathrm{NO}_{2}$ grew at most grid cells from 2005 to 2013, with a regional average annual growth at $8.6 \pm 0.9 \% \mathrm{yr}^{-1} . \mathrm{NO}_{2}$ grew the fastest over the city clusters, reflecting rapid economic development, urbanization, and population growth. Parts of Chengdu-Chongqing, Shaanxi-Guanzhong and Urumqi city clusters experienced $\mathrm{NO}_{2}$ growth of $15 \% \mathrm{yr}^{-1}$ or more. Most grid cells in yellow color are suburban or rural areas, but they have also undergone rapid $\mathrm{NO}_{2}$ growth since $2005\left(6-10 \% \mathrm{yr}^{-1}\right)$.

Table 1 shows the trends of $\mathrm{OMI} \mathrm{NO} \mathrm{NCDs}_{2}$ from 2005 to 2013 , as a percentage of mean values in 2005 , on a provincial basis. $\mathrm{NO}_{2}$ grew the fastest over Xinjiang, Ningxia and Qinghai with a growth rate at $15.1,12.3$ and $11.2 \%$ per year, respectively. The growth rates in Northwestern China $\left(7.5-15.1 \% \mathrm{yr}^{-1}\right)$ were much greater than the rates in Southwestern China $\left(4.0-7.8 \% \mathrm{yr}^{-1}\right)$, primarily as a result of the regional differences in socioeconomic development (see Sect. 5.2).

A comparison of Fig. 5b and c shows that GEOS-Chem generally captures the $\mathrm{OMI} \mathrm{NO}$ trends from 2005 to 2012, suggesting that anthropogenic emissions are the main driver of the observed $\mathrm{NO}_{2}$ trend. OMI data exhibit stronger growth than modeled data over North Xinjiang, East and South Inner Mongolia, South Sichuan, East Guizhou and South Guangxi, whereas the OMI trends are weaker than the modeled trends over most other regions. The differences between modeled and $\mathrm{OMI} \mathrm{NO} \mathrm{N}_{2}$ reflect the strong but nonlinear relation between $\mathrm{NO}_{x}$ emissions and $\mathrm{NO}_{2}$ VCDs.

To further confirm that anthropogenic emissions are the main driver of the observed $\mathrm{NO}_{2}$ trends, we conducted an additional model simulation for 2012 where anthropogenic 

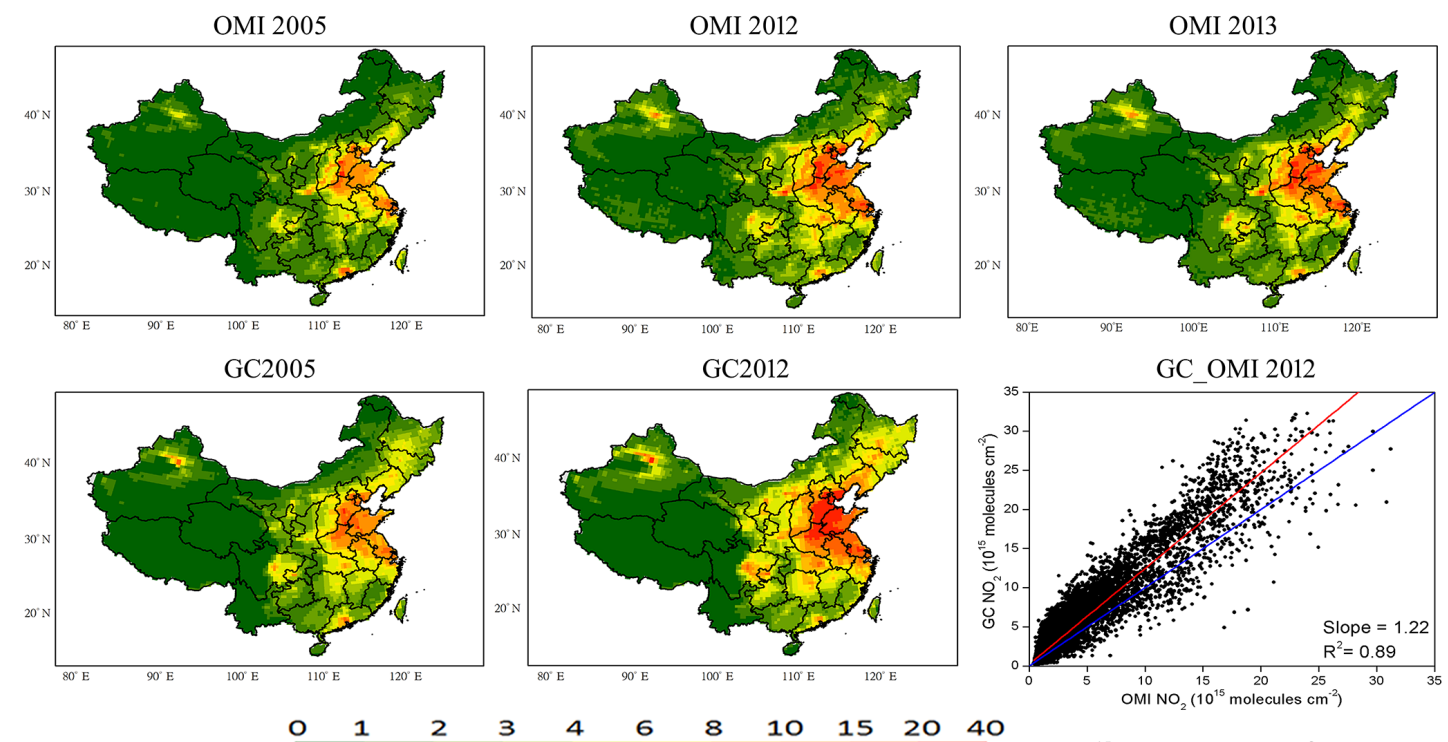

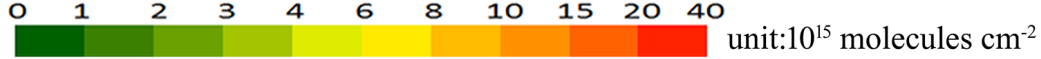

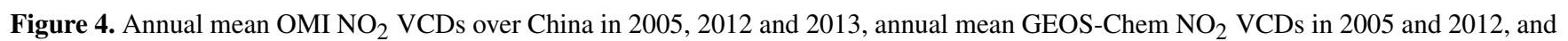
a scatterplot with linear regression for model vs. $\mathrm{OMI} \mathrm{NO}_{2}$ in 2012. In the scatterplot, the red line represents a linear fit, and the blue line is the $1: 1$ line.

Table 2. Linear regression for GEOS-Chem modeled annual mean $\mathrm{NO}_{2}$ VCDs as a function of OMI values over China and Western China.

\begin{tabular}{lcccccccr}
\hline Year & 2005 & 2006 & 2007 & 2008 & 2009 & 2010 & 2011 & 2012 \\
\hline China & & & & & & & & \\
\hline Slope & 1.11 & 1.18 & 1.19 & 1.09 & 1.15 & 1.17 & 1.26 & 1.22 \\
Intercept & 0.26 & 0.33 & 0.36 & 0.32 & 0.27 & 0.32 & 0.31 & 0.21 \\
$R^{2}$ & 0.88 & 0.86 & 0.89 & 0.88 & 0.88 & 0.89 & 0.90 & 0.89 \\
\hline \multicolumn{2}{l}{ Western China } & & & & & & & \\
\hline Slope & 1.17 & 1.16 & 1.22 & 1.08 & 1.19 & 1.18 & 1.23 & 1.26 \\
Intercept & 0.05 & 0.07 & 0.01 & 0.03 & 0.08 & -0.01 & 0.00 & -0.13 \\
$R^{2}$ & 0.70 & 0.68 & 0.71 & 0.72 & 0.74 & 0.76 & 0.76 & 0.75 \\
\hline
\end{tabular}

emissions are fixed at the 2005 levels (while natural emissions and meteorology correspond to the 2012 levels). We contrasted the model $\mathrm{NO}_{2}$ change from 2005 to 2012 in this case to the standard case that has included year-specific anthropogenic emissions. Table 3 shows that inclusion of anthropogenic emission changes from 2005 to 2012 leads to large changes in model $\mathrm{NO}_{2}$, and keeping anthropogenic emissions unchanged leads to much reduced changes in $\mathrm{NO}_{2}$. The $\mathrm{NO}_{2}$ growth reduces from 85.8 to $6.9 \%$ averaged over the northwestern provinces and from 46.8 to $-6.3 \%$ over Southwestern China.

\subsection{2 $\mathrm{NO}_{2}$ time series}

Figure 6 further shows the $A_{5}$ monthly time series for individual provinces as a result of wavelet analyses on OMI $\mathrm{NO}_{2}$. All values are normalized with respect to 2005. In par- ticular, the OMI_1 time series (black line) results from a wavelet analysis on OMI NO 2 over October 2004-May 2014. OMI_1 shows that $\mathrm{NO}_{2}$ grew rapidly between 2007 and 2011 over all provinces. For Xinjiang, Qinghai and Yunnan, OMI $\mathrm{NO}_{2}$ increased continuously from 2005 to 2013 . Over other provinces, OMI $\mathrm{NO}_{2}$ peaked around 2011-2012 and then stagnated or even slightly declined thereafter. These stagnation or reduction patterns likely reflect recent effective emission control policies (see Sect. 5.1).

Figure 6 also compares the $A_{5}$ time series for $\mathrm{OMI} \mathrm{NO}_{2}$ (OMI_2, green line) and model $\mathrm{NO}_{2}$ (GC_AK, red line) derived from wavelet analyses on the same period from January 2005 to April 2013. Model results were sampled coincidently with OMI data and were applied with the AK. OMI_2 and GC_AK do not show a stagnation or reduction feature as obvious as OMI_1 after 2011, because of a shorter time series for wavelet decomposition. OMI_2 and GC_AK ex- 
(a) OMI 2005-2013

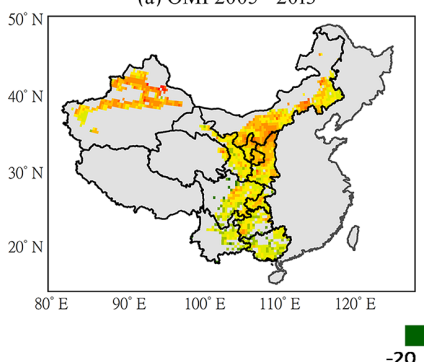

(b) OMI 2005-2012

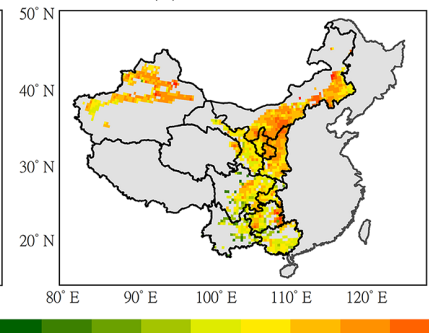

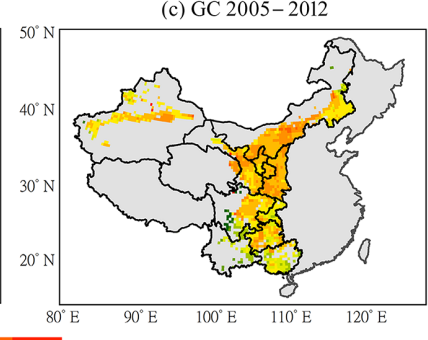

Figure 5. Percentage trends of annual mean OMI and Model $\mathrm{NO}_{2}$ VCDs over Western China (relative to 2005), by applying a linear regression to the approximation signal $A_{5}$ from the wavelet decomposition. All the $\mathrm{NO}_{2}$ data have been subtracted by their respective "background" values prior to the wavelet decomposition. Results are shown only for grid cells with 2005-2013 average $\mathrm{NO}_{2} \mathrm{VCDs}$ exceeding $1.0 \times 10^{15}$ molecules $\mathrm{cm}^{-2}$ and with statistically significant trends ( $P$ value $<0.05$ according to an $F$ test). (a) $\mathrm{OMI} \mathrm{NO}_{2}$ trends from 2005 to 2013, (b) $\mathrm{OMI} \mathrm{NO}_{2}$ trends from 2005 to 2012, (c) Model NO 2 trends from 2005 to 2012.

Table 3. Percentage changes in modeled $\mathrm{NO}_{2}$ from 2005 to 2012.

\begin{tabular}{llrr}
\hline Region & $\begin{array}{r}\text { With changes in } \\
\text { anthropogenic emissions }\end{array}$ & $\begin{array}{r}\text { Without changes in } \\
\text { anthropogenic emissions }\end{array}$ \\
\hline \multirow{5}{*}{ Northwest } & Gansu & 70.9 & -8.4 \\
& Inner-Mongolia & 129.3 & 21.9 \\
& Ningxia & 94.9 & -1.2 \\
& Qinghai & 102.2 & 12.6 \\
& Shaanxi & 81.6 & -6.6 \\
& Xinjiang & 51.8 & 1.5 \\
\hline \multirow{5}{*}{ Southwest } & Ghongqing & 54.1 & -2.7 \\
& Guangxi & 27.0 & -16.6 \\
& Sichuan & 71.1 & 3.2 \\
& Yunnan & 52.2 & -5.1 \\
& West & 9.4 & -10.7 \\
\hline \multirow{5}{*}{ Region } & Northwest & 70.4 & 1.6 \\
& Southwest & 85.8 & 6.9 \\
& BTH & 46.8 & -6.3 \\
& YRD & 62.5 & 1.9 \\
& PRD & 40.4 & 3.2 \\
& & -30.4 & -0.6 \\
\hline
\end{tabular}

hibit similar increasing trends and variability in most western provinces, consistent with the finding in Sect. 4.2.1 that variations in anthropogenic emissions (accounted for in the model) were the main driver of $\mathrm{NO}_{2}$ changes.

Our trend analyses may be affected by missing OMI data and the corresponding temporal interpolation procedure. To evaluate the effects, we compared two additional data sets based on model results: GC_NAK1 (blue line in Fig. 6) represents model $\mathrm{NO}_{2}$ on all days without applying the $\mathrm{AK}$, and GC_NAK2 (orange line) represents model $\mathrm{NO}_{2}$ sampled from days with valid OMI data but without applying the AK. Figure 6 shows almost no differences between GC_NAK1 and GC_NAK2 for all provinces. Therefore, the missing data have little influence on our trend analyses.

\subsection{Comparison between satellite observations and bottom-up anthropogenic emission estimates}

Figure 7 shows Chinese official bottom-up provincial anthropogenic emission inventory for 2007 and 2010-2013, together with the provincial emission targets for 2015 (as a goal of the 12th Five-Year Plan) (The State Council of the People's Republic of China, 2011a). Provincial mean OMI $\mathrm{NO}_{2}$ VCDs are also shown for comparison. Both emission and VCD data sets were normalized to their 2007 mean values to remove the effect of regional dependence in the relation between $\mathrm{NO}_{x}$ emissions and $\mathrm{NO}_{2}$ VCDs. Ningxia, Xinjiang and Inner Mongolia had the largest increases in $\mathrm{NO}_{x}$ emissions from 2007 to 2010, consistent with their growth of $\mathrm{NO}_{2}$ VCDs. $\mathrm{NO}_{x}$ emissions in most provinces grew significantly 


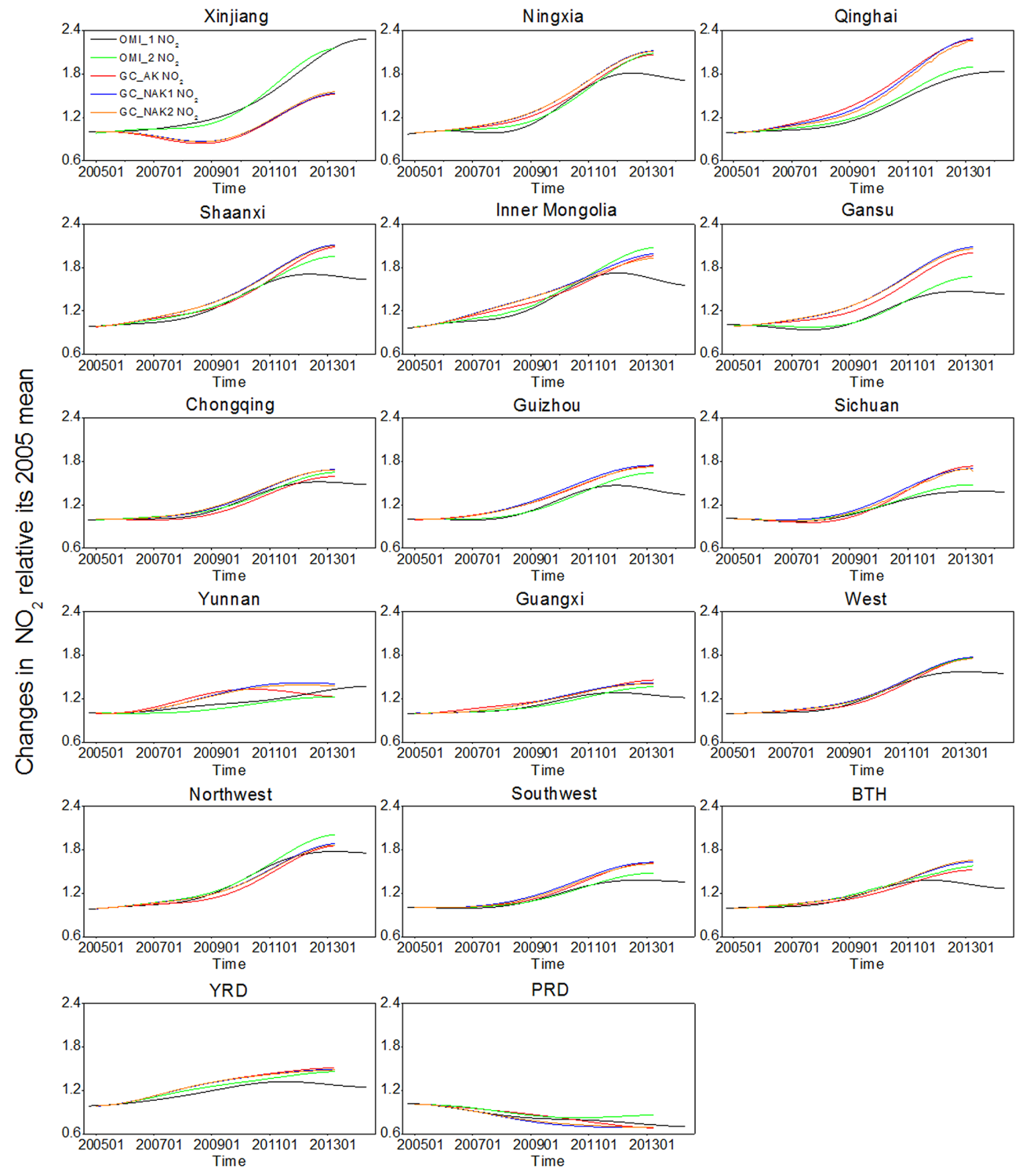

Figure 6. The long-term trends (i.e., the $A_{5}$ component out of the wavelet analysis) of $\mathrm{OMI}$ and modeled $\mathrm{NO}_{2}$ in individual provinces and regions. The values are normalized to 2005. OMI_1 (black line) denotes the $A_{5}$ signal from a wavelet analysis of OMI NO 2 over October 2004-May 2014, and OMI_2 (green line) corresponds to the wavelet analysis over January 2005-April 2013. GC_AK (red line) corresponds to a wavelet analysis of coincident modeled values (applied with the AK) over January 2005-April 2013. GC_NAK1 (blue line) represents the $A_{5}$ signal for modeled $\mathrm{NO}_{2}$ on all days (without applying the AK) over January 2005-April 2013, and GC_NAK2 (orange line) is similar to GC_NAK1 but with model results coincident with valid OMI data.

from 2007 to 2010 and peaked in 2011-2012, also in general consistency with the trends in $\mathrm{OMI} \mathrm{NO}_{2}$. On the other hand, the emission inventory suggests a reduction since 2011 for Xinjiang and Yunnan, inconsistent with the notable growth in $\mathrm{NO}_{2}$ VCDs. This likely suggests an underestimate in the official emission inventory.

\section{Relating pollution changes to socioeconomic development and environmental policies}

\subsection{General discussion on $\mathrm{NO}_{2}$ trends over Western China}

As described in Sect. 4, the tropospheric $\mathrm{NO}_{2} \mathrm{VCDs}$ over Western China have grown notably since 2005. The growth occurred not only over cities but also over many suburban and rural regions, indicating an expansion of human influences from urban to remote areas. This scale of pollution 


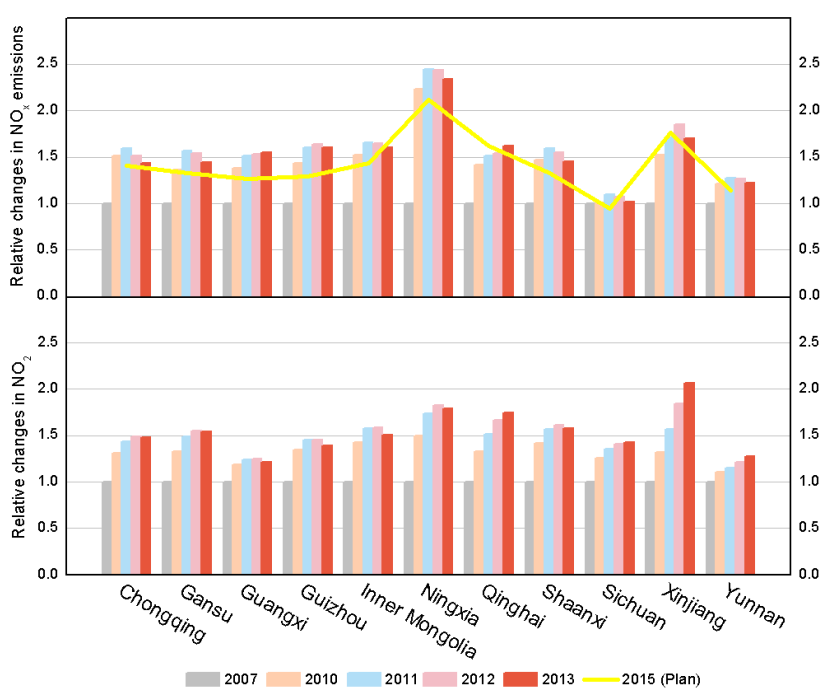

Figure 7. Relative Changes in $\mathrm{OMI} \mathrm{NO}_{2} \mathrm{VCDs}$ and $\mathrm{NO}_{x}$ emissions in 2007 and 2010-2013 (relative to 2007). (Top) Chinese official provincial-level $\mathrm{NO}_{x}$ emission inventory for 2007 and 2010-2013 as well as its targeted emissions for 2015. (Bottom) Annual mean $\mathrm{OMI} \mathrm{NO}_{2}$ levels in 2007 and 2010-2013.

growth was associated with the rapid urbanization and industrialization over Western China following the "Go West" movement. Table 4 shows that the urban population (i.e., the percentage of total population living in urban areas) increased by $10 \%$ or more from 2005 to 2013 in all provinces of Western China except Xinjiang. Over the same period, Western China experienced steep economic growth with industrial GDP growth rates of $12.4-20.3 \% \mathrm{yr}^{-1}$ across the provinces.

On the other hand, the $\mathrm{NO}_{2}$ VCDs declined or stabilized since 2011 in many provinces (see Fig. 6), partly reflecting some improvements in environmental strategies. China's air pollution control strategy has been transformed from a traditional end-of-pipe control strategy (i.e., only using low $\mathrm{NO}_{x}$ combustion technologies in some power plants) into a combined energy saving and emission reduction strategy after 2006 (Gu et al., 2013; Zhao et al., 2013). In particular, total $\mathrm{NO}_{x}$ emissions have become a major target of national pollution control in the 12th Five-Year Plan (2011-2015), with a legally binding goal to reduce the national emissions by nearly $10 \%$ in 2015 compared to 2010 (The State Council of the People's Republic of China, 2011b). Furthermore, the Chinese central government has also decided to consider the effectiveness of this reduction in evaluating local governments' performance (The State Council of the People's Republic of China, 2012). Regarding energy saving measures, great efforts have also been made to improve energy efficiency, to slow down growth of energy demand, and to adjust structure in various sectors (power plants, transportation, industries, and residential use) over the past few years (Wang and Hao, 2012; Zhao et al., 2013).

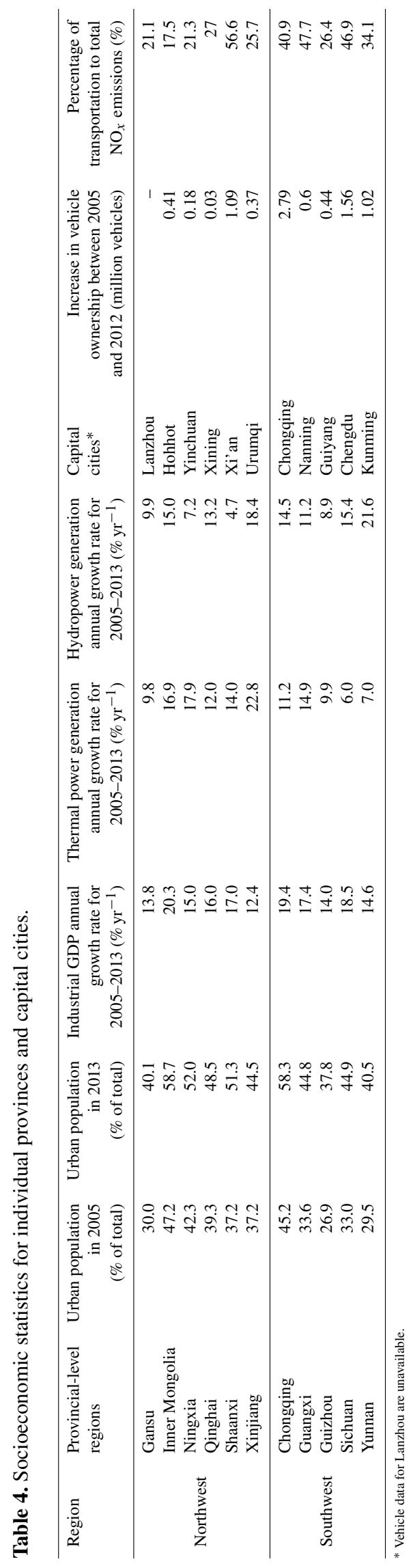

Atmos. Chem. Phys., 16, 6207-6221, 2016 


\subsection{On the contrast between Northwestern and Southwestern China}

Northwestern China (Inner Mongolia, Xinjiang, Qinghai, Gansu and Shaanxi) has an average $\mathrm{NO}_{2}$ growth rate at $11.3 \pm 1.0 \% \mathrm{yr}^{-1}$ from 2005 to 2013 , about twice the average growth rate $\left(5.9 \pm 0.6 \% \mathrm{yr}^{-1}\right)$ in Southwestern China (Sichuan, Chongqing, Guizhou, Guangxi and Yunnan). The contrast in $\mathrm{NO}_{2}$ growth rate between Northwest and Southwest reflects their distinctive states of socioeconomic development. According to the nationwide pollution census, Northwestern China generates much more $\mathrm{NO}_{x}$ emissions per unit of GDP (11.94 t/billion RMB in 2007) than the Southwest (6.98 t/billion RMB) (The first nationwide pollution census committee, 2011). The difference in pollution intensities also reflects their dissimilar economic structures. In particular, Northwestern China has recently become an important energy producer (due to the "West to East Power Transmission" project) and a heavy industry base (in terms of mining, fossil fuels and raw materials)(Chen et al., 2010; Deng and Bai, 2014), and these industries are often associated with significant $\mathrm{NO}_{x}$ emissions. The electricity consumption of heavy industries in Northwestern China grew by $152.5 \%$ from 2005 to 2011 , greater than the growth at $99.6 \%$ in Southwestern China.

About $70 \%$ of China's industrial and residential energy consumption is supplied by coal burning in 2009 ( $\mathrm{Li}$ and Leung, 2012), and the value did not changed drastically in later years. Figure 8 shows that Northwestern China has consumed more coal than the Southwest since 2005, and by 2012 their difference has increased by a factor of 35 (from merely 9.03 million tonnes in 2005 to as large as 318.3 million tonnes in 2012). For the Northwest, there is an extremely high correlation between $\mathrm{NO}_{2}$ VCDs and coal use across the years $\left(R^{2}=0.95, P\right.$ value $\left.<0.05\right)$, compared to a correlation at $0.84(P$ value $<0.05)$ for the Southwest.

Furthermore, the annual amount of electricity generated by coal-fired power plants in Northwestern China increased by $237 \%$, from 226.3 billion $\mathrm{kWh}$ in 2005 to 763.1 billion $\mathrm{kWh}$ in 2013; the annual growth rates are 9.8$22.8 \% \mathrm{yr}^{-1}$ for individual provinces (see Table 4). The growth was much smaller in the Southwest, about $110 \%$ from 165.6 to 347.9 billion $\mathrm{kWh}$, translated to growth rates of $6.0-14.9 \% \mathrm{yr}^{-1}$ for individual provinces. This difference was partly due to the stronger growth in hydropower production in the Southwest (from 147.2 to 471.6 billion kWh over 2005-2013, at the rates of $8.9-21.6 \% \mathrm{yr}^{-1}$ in individual provinces) than the growth in the Northwest (from 40.0 to 107.3 billion $\mathrm{kWh}, 4.7-18.4 \% \mathrm{yr}^{-1}$ ).

Transportation plays a more important role in $\mathrm{NO}_{x}$ pollution over the Southwest compared to the Northwest. Table 4 shows that transportation contributes to much larger fractions of $\mathrm{NO}_{x}$ emissions in the capital cities of Southwestern China than in the Northwestern capital cities except Xi' an, Shaanxi.

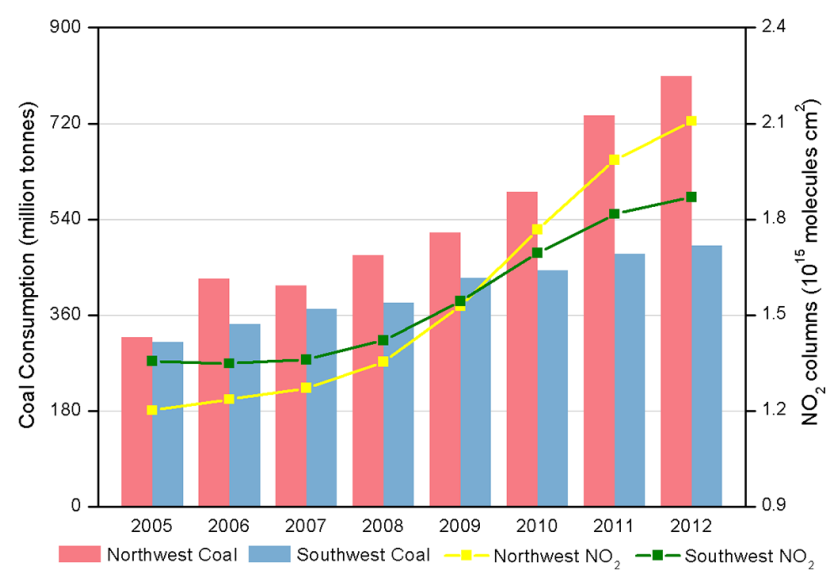

Figure 8. Coal consumption and annual mean $\mathrm{OMI} \mathrm{NO}_{2}$ levels over Western China.

In addition, the number of vehicles grew faster in the Southwestern capital cities during 2005-2012.

\subsection{On the contrast between Western and Eastern China}

The average $\mathrm{NO}_{2}$ growth rate was $8.6 \pm 0.9 \% \mathrm{yr}^{-1}$ for Western China, much larger than the rates in the three key eastern regions BTH $\left(5.3 \pm 0.8 \% \mathrm{yr}^{-1}\right)$, YRD $\left(4.0 \pm 0.6 \% \mathrm{yr}^{-1}\right)$ and PRD $\left(-3.3 \pm 0.3 \% \mathrm{yr}^{-1}\right)$ (see Table 1$)$. This regional contrast reflects both their economic activities and the emission control policies adopted by the Chinese central and local governments. In particular, China's development strategy for its western provinces might have led to unintended westward pollution migration, as many resource- and pollutionintensive industries gradually moved from the East to the West after 2000. Table 4 shows that from 2005 to 2013, the average industrial GDP growth rate in Western China was $17.2 \% \mathrm{yr}^{-1}$ (relative to 2005), higher than the rates in the three key eastern regions (13.2\% $\mathrm{yr}^{-1}$ in BTH, $11.6 \% \mathrm{yr}^{-1}$ in YRD and $12.0 \% \mathrm{yr}^{-1}$ in PRD). The fast economic and pollution growth in Western China in part reflects its growing production to support consumption in other regions (Lin et al., 2014a; Zhao et al., 2015). According to Zhao et al. (2015), $\mathrm{NO}_{x}$ emissions over Western China in 2007 were largely attributable to the economic production to supply Eastern China and foreign countries, with $366 \mathrm{Gg}$ related to interprovincial trade and $49.1 \mathrm{Gg}$ related to international trade. Together with atmospheric transport, trade has become a critical mechanism for transboundary pollution transfer at both the global and regional scales (Lin et al., 2014a), with significant consequences on public health (Jiang et al., 2015).

The west-east contrast in $\mathrm{NO}_{2}$ growth also reflected their different pollution control strategies and measures. Although China has a national $\mathrm{NO}_{x}$ emission reduction target at $10 \%$ (from 2010 to 2015), the targets are set differently for individual provinces. Table 1 shows that the targets were higher, 
at $13.9,17.7$ and $16.9 \%$, for the three key eastern regions (BTH, YRD, and PRD), but they are as low as $5.7 \%$ averaged over Western China (The State Council of the People's Republic of China, 2011a). In particular, an emission increase by $15 \%$ is allowed for Qinghai Province. In addition, although $\mathrm{NO}_{x}$ emission reduction measures have been taken in power plants and some other industrial sectors since 2006 (via de-nitrification systems that involve selective catalytic or non-catalytic reduction), by 2010 as much as $57 \%$ of these systems were installed in the three key eastern regions (Zhao et al., 2013). The capacity of small power generators being shut-down in Western China was about 10808 MW (excluding small diesel generators), only accounting for about $19 \%$ of the capacity of total shut-down small power plants in China (55 $630 \mathrm{MW}$ ) during the 11th Five-Year Plan period (2006-2010) (NDRC, 2009-2011; Xu et al., 2013).

Furthermore, the vehicle emission control has also been implemented much more stringently in the East than in the West ( $\mathrm{Li}$ and Leung, 2012). Although large amounts of "Yellow-Label Vehicles" (YLVs, highly-emitting vehicles that fail to meet the National I emission standard) have been banned from entering into big cites in Eastern China, over recent years a considerable number of used YLVs have been brought to the West, where the restrictions on YLVs are much weaker (Qi, 2010). Greater efforts to reduce $\mathrm{NO}_{x}$ pollution in Western China, with lessons learnt from the East, will help to achieve its sustainable development.

\section{Conclusion}

This study investigates the spatiotemporal variations of tropospheric $\mathrm{NO}_{2}$ VCDs over Western China during 20052013, by using a wavelet decomposition analysis to distinguish long-term trends and other scales of temporal variability. We focus on the anthropogenic $\mathrm{NO}_{2}$ by subtracting region-specific "background" values dominated by natural sources. We find that the anthropogenic $\mathrm{NO}_{2}$ grew rapidly over Western China at a regional average rate of $8.6 \pm 0.9 \% \mathrm{yr}^{-1}$ from 2005 to 2013 . Under the competing influences of economic growth and emission control, $\mathrm{NO}_{2} \mathrm{lev}$ els in most western provinces increased from 2005 to 2011 and stabilized or slightly declined afterwards. GEOS-Chem model simulations and the official emission statistics are used to confirm that the OMI-observed $\mathrm{NO}_{2}$ trends were driven mainly by changes in anthropogenic emissions.

Between 2005 and 2013, Northwestern China experienced much larger $\mathrm{NO}_{2}$ growth $\left(11.3 \pm 1.0 \% \mathrm{yr}^{-1}\right)$ than Southwestern China $\left(5.9 \pm 0.6 \% \mathrm{yr}^{-1}\right)$ and the three traditional key regions of Eastern China (BTH, YRD and PRD, $\left.(-3.3)-(+5.3) \% \mathrm{yr}^{-1}\right)$. The rapid $\mathrm{NO}_{2}$ growth in Northwestern China was possibly attributed to the fast developing resource- and pollution-intensive industries along with the "Go West" movement as well as relatively weak emission controls. Rapid industrialization and urbanization in Western
China should be accompanied with more stringent pollution control to achieve sustainable development.

\section{Data availability}

The DOMINO v2 data are available at the TEMIS web site (http://www.temis.nl/airpollution/no2.html).

Acknowledgements. This research is supported by the National Natural Science Foundation of China, grant 41175127 and 41422502, and by the 973 program, grant 2014CB441303. We acknowledge the free use of DOMINO v2 $\mathrm{NO}_{2}$ product from www.temis.nl.

Edited by: G. Carmichael

\section{References}

Abry, P.: Ondelettes et turbulence, Diderot ed., Paris, France, 1997. Bai, X., Shi, P., and Liu, Y.: Realizing China's urban dream, Nature, 509, 158-160, doi:10.1038/509158a, 2014.

Boersma, K. F., Eskes, H. J., Veefkind, J. P., Brinksma, E. J., van der A, R. J., Sneep, M., van den Oord, G. H. J., Levelt, P. F., Stammes, P., Gleason, J. F., and Bucsela, E. J.: Near-real time retrieval of tropospheric $\mathrm{NO}_{2}$ from OMI, Atmos. Chem. Phys., 7, 2103-2118, doi:10.5194/acp-7-2103-2007, 2007.

Boersma, K. F., Eskes, H. J., Dirksen, R. J., van der A, R. J., Veefkind, J. P., Stammes, P., Huijnen, V., Kleipool, Q. L., Sneep, M., Claas, J., Leitão, J., Richter, A., Zhou, Y., and Brunner, D.: An improved tropospheric $\mathrm{NO}_{2}$ column retrieval algorithm for the Ozone Monitoring Instrument, Atmos. Meas. Tech., 4, 19051928, doi:10.5194/amt-4-1905-2011, 2011.

Boersma, K. F., Eskes, H. J., Dirksen, R. J., van der A, R. J., Veefkind, J. P., Stammes, P., Huijnen, V., Kleipool, Q. L., Sneep, M., Claas, J., Leitao, J., Richter, A., Zhou, Y., and Brunner, D.: OMI NO 2 data set DOMINO v2, available at: http://www.temis. nl/airpollution/no2.html (last access: 25 March 2015), 2011.

Chen, D., Wang, Y., McElroy, M. B., He, K., Yantosca, R. M., and Le Sager, P.: Regional CO pollution and export in China simulated by the high-resolution nested-grid GEOS-Chem model, Atmos. Chem. Phys., 9, 3825-3839, doi:10.5194/acp-9-3825-2009, 2009.

Chen, W., Li, H., and Wu, Z.: Western China energy development and west to east energy transfer: Application of the Western China Sustainable Energy Development Model, Energ. Policy, 38, 7106-7120, doi:10.1016/j.enpol.2010.07.029, 2010.

Chen, X., Feng, Y., and Huang, N. E.: Global sea level trend during 1993-2012, Global Planet. Change, 112, 26-32, doi:10.1016/j.gloplacha.2013.11.001, 2014.

Daubechies, I.: Ten Lectures on Wavelets, CBMS-NSF Regional Conference Series in Applied Mathematics 61, Society for Industrial and Applied Mathematics, Philadelphia, PA, USA, 377 pp., 1992.

Deng, X. and Bai, X.: Sustainable Urbanization in Western China, Environment: Science and Policy for Sustainable Development, 56, 12-24, doi:10.1080/00139157.2014.901836, 2014. 
Echer, E.: Multi-resolution analysis of global total ozone column during 1979-1992 Nimbus-7 TOMS period, Ann. Geophys., 22, 1487-1493, doi:10.5194/angeo-22-1487-2004, 2004.

Freitas, R. M. and Shimabukuro, Y. E.: Combining wavelets and linear spectral mixture model for MODIS satellite sensor timeseries analysis, Journal of Computational Interdisciplinary Sciences, 1, 33-38, doi:10.6062/jcis.2008.01.01.0005, 2008.

Gu, D., Wang, Y., Smeltzer, C., and Liu, Z.: Reduction in $\mathrm{NO}_{x}$ Emission Trends over China: Regional and Seasonal Variations, Environ. Sci. Technol., 47, 12912-12919, doi:10.1021/es401727e, 2013.

Hao, N., Valks, P., Loyola, D., Cheng, Y. F., and Zimmer, W.: Spacebased measurements of air quality during the World Expo 2010 in Shanghai, Environ. Res. Lett., 6, 044004, doi:10.1088/17489326/6/4/044004, 2011.

He, Y., Uno, I., Wang, Z., Ohara, T., Sugimoto, N., Shimizu, A., Richter, A., and Burrows, J. P.: Variations of the increasing trend of tropospheric $\mathrm{NO}_{2}$ over central east China during the past decade, Atmos. Environ., 41, 4865-4876, doi:10.1016/j.atmosenv.2007.02.009, 2007.

Huang, J., Zhou, C., Lee, X., Bao, Y., Zhao, X., Fung, J., Richter, A., Liu, X., and Zheng, Y.: The effects of rapid urbanization on the levels in tropospheric nitrogen dioxide and ozone over East China, Atmos. Environ., 77, 558-567, doi:10.1016/j.atmosenv.2013.05.030, 2013.

Jiang, X., Zhang, Q., Zhao, H., Geng, G., Peng, L., Guan, D., Kan, H., Huo, H., Lin, J., Brauer, M., Martin, R. V., and He, K.: Revealing the Hidden Health Costs Embodied in Chinese Exports, Environ. Sci. Technol., 49, 4381-4388, doi:10.1021/es506121s, 2015.

Lamsal, L. N., Martin, R. V., Padmanabhan, A., van Donkelaar, A., Zhang, Q., Sioris, C. E., Chance, K., Kurosu, T. P., and Newchurch, M. J.: Application of satellite observations for timely updates to global anthropogenic $\mathrm{NO}_{x}$ emission inventories, Geophys. Res. Lett., 38, L05810, doi:10.1029/2010GL046476, 2011.

Li, C., Zhang, Q., Krotkov, N. A., Streets, D. G., He, K., Tsay, S.-C., and Gleason, J. F.: Recent large reduction in sulfur dioxide emissions from Chinese power plants observed by the Ozone Monitoring Instrument, Geophys. Res. Lett., 37, L08807, doi:10.1029/2010GL042594, 2010.

Li, R. and Leung, G. C. K.: Coal consumption and economic growth in China, Energ. Policy, 40, 438-443, doi:10.1016/j.enpol.2011.10.034, 2012.

Lin, J.-T.: Satellite constraint for emissions of nitrogen oxides from anthropogenic, lightning and soil sources over East China on a high-resolution grid, Atmos. Chem. Phys., 12, 2881-2898, doi:10.5194/acp-12-2881-2012, 2012.

Lin, J.-T. and McElroy, M. B.: Detection from space of a reduction in anthropogenic emissions of nitrogen oxides during the Chinese economic downturn, Atmos. Chem. Phys., 11, 8171-8188, doi:10.5194/acp-11-8171-2011, 2011

Lin, J.-T., Nielsen, C. P., Zhao, Y., Lei, Y., Liu, Y., and McElroy, M. B.: Recent Changes in Particulate Air Pollution over China Observed from Space and the Ground: Effectiveness of Emission Control, Environ. Sci. Technol., 44, 7771-7776, doi:10.1021/es101094t, 2010a.

Lin, J.-T., McElroy, M. B., and Boersma, K. F.: Constraint of anthropogenic $\mathrm{NO}_{x}$ emissions in China from different sectors: a new methodology using multiple satellite retrievals, Atmos. Chem. Phys., 10, 63-78, doi:10.5194/acp-10-63-2010, $2010 \mathrm{~b}$.

Lin, J.-T., Pan, D., and Zhang, R.-X.: Trend and interannual variability of Chinese air pollution since 2000 in association with socioeconomic development: A brief overview, Atmos. Ocean. Sci. Lett, 6, 84-89, 2013.

Lin, J.-T., Pan, D., Davis, S. J., Zhang, Q., He, K., Wang, C., Streets, D. G., Wuebbles, D. J., and Guan, D.: China's international trade and air pollution in the United States, P. Natl. Acad. Sci., 111, 1736-1741, doi:10.1073/pnas.1312860111, 2014a.

Lin, J.-T., Martin, R. V., Boersma, K. F., Sneep, M., Stammes, P., Spurr, R., Wang, P., Van Roozendael, M., Clémer, K., and Irie, H.: Retrieving tropospheric nitrogen dioxide from the Ozone Monitoring Instrument: effects of aerosols, surface reflectance anisotropy, and vertical profile of nitrogen dioxide, Atmos. Chem. Phys., 14, 1441-1461, doi:10.5194/acp-14-1441-2014, 2014b.

Lin, J.-T., Liu, M.-Y., Xin, J.-Y., Boersma, K. F., Spurr, R., Martin, R., and Zhang, Q.: Influence of aerosols and surface reflectance on satellite $\mathrm{NO}_{2}$ retrieval: seasonal and spatial characteristics and implications for $\mathrm{NO}_{x}$ emission constraints, Atmos. Chem. Phys., 15, 11217-11241, doi:10.5194/acp-15-11217-2015, 2015.

Martin, R. V., Jacob, D. J., Chance, K., Kurosu, T. P., Palmer, P. I., and Evans, M. J.: Global inventory of nitrogen oxide emissions constrained by space-based observations of $\mathrm{NO}_{2}$ columns, J. Geophys. Res.-Atmos., 108, 4537, doi:10.1029/2003JD003453, 2003.

Martínez, B. and Gilabert, M. A.: Vegetation dynamics from NDVI time series analysis using the wavelet transform, Remote Sens. Environ., 113, 1823-1842, doi:10.1016/j.rse.2009.04.016, 2009.

Mijling, B., van der A, R. J., Boersma, K. F., Van Roozendael, M., De Smedt, I., and Kelder, H. M.: Reductions of $\mathrm{NO}_{2}$ detected from space during the 2008 Beijing Olympic Games, Geophys. Res. Lett., 36, L13801, doi:10.1029/2009GL038943, 2009.

NDRC (National Development and Reform Commission): List of Decommissioned Small Thermal Power Plants, available at: http: //bgt.ndrc.gov.cn/zcfb/ (last access: 5 March 2014), 2009-2011 (in Chinese).

Partal, T. and Küçük, M.: Long-term trend analysis using discrete wavelet components of annual precipitations measurements in Marmara region (Turkey), Phys. Chem. Earth Pt. A, B, C, 31, 1189-1200, doi:10.1016/j.pce.2006.04.043, 2006.

Percival, D. B. and Walden, A. T.: Wavelet Methods for Time Series Analysis, Cambridge University Press, Cambridge, UK, 2006.

Qi, J.: Odd phenomenon develops in used car market, do the "Yellow-label vehicles" restrictions work to mitigate air pollution, Xinhuanet, available at: http://news.xinhuanet.com/society/ 2010-11/28/c_12825457.htm (last access: 6 October 2015), 2010 (in Chinese).

Reuter, M., Buchwitz, M., Hilboll, A., Richter, A., Schneising, O., Hilker, M., Heymann, J., Bovensmann, H., and Burrows, J. P.: Decreasing emissions of $\mathrm{NO}_{x}$ relative to $\mathrm{CO}_{2}$ in East Asia inferred from satellite observations, Nat. Geosci., 7, 792-795, doi:10.1038/ngeo2257, 2014.

Richter, A., Burrows, J. P., Nusz, H., Granier, C., and Niemeier, U.: Increase in tropospheric nitrogen dioxide over China observed from space, Nature, 437, 129-132, doi:10.1038/nature04092, 2005. 
Rienecker, M., Suarez, M., Todling, R., Bacmeister, J., Takacs, L., Liu, H., Gu, W., Sienkiewicz, M., Koster, R., and Gelaro, R.: The GEOS-5 Data Assimilation System - Documentation of Versions 5.0. 1, 5.1. 0, and 5.2. 0, NASA Tech. Memo, 104606, National Aeronautics and Space Administration, Washington, DC, USA, 2008.

Russell, A. R., Valin, L. C., and Cohen, R. C.: Trends in $\mathrm{OMI} \mathrm{NO}_{2}$ observations over the United States: effects of emission control technology and the economic recession, Atmos. Chem. Phys., 12, 12197-12209, doi:10.5194/acp-12-12197-2012, 2012.

Shao, S. and Qi, Z.: Energy Development and Economic Growth in Western China: An Empirical Analysis Based on the Resource Curse Hypothesis, Economic Research Journal, 4, 147160, 2008 (in Chinese).

Stavrakou, T., Müller, J. F., Boersma, K. F., De Smedt, I., and van $\operatorname{der}$ A, R. J.: Assessing the distribution and growth rates of $\mathrm{NO}_{x}$ emission sources by inverting a 10-year record of $\mathrm{NO}_{2}$ satellite columns, Geophys. Res. Lett., 35, L10801, doi:10.1029/2008GL033521, 2008.

The first nationwide pollution census committee: Pollution Census Dataset, China Environmental Science Press, Beijing, China, 2011 (in Chinese).

The State Council of the People's Republic of China: Integrated Work Plan for Energy Saving and Emission Reduction During the Twelfth Five-Year Plan, available at: http://www.gov. cn/zwgk/2011-09/07/content_1941731.htm (last access: 10 June 2015), 2011a (in Chinese).

The State Council of the People's Republic of China: The Twelfth Five-Year Plan for Environmental Protection, available at: http: //www.gov.cn/zwgk/2011-12/20/content_2024895.htm (last access: 10 June 2015), 2011 b (in Chinese).

The State Council of the People's Republic of China: The Twelfth Five-Year Plan for Energy Saving and Emission Reduction, available at: http://www.gov.cn/zwgk/2012-08/21/content_ 2207867.htm (last access: 10 June 2015), 2012 (in Chinese).

Valin, L. C., Russell, A. R., Hudman, R. C., and Cohen, R. C.: Effects of model resolution on the interpretation of satellite $\mathrm{NO}_{2}$ observations, Atmos. Chem. Phys., 11, 11647-11655, doi:10.5194/acp-11-11647-2011, 2011.

van der A, R. J., Peters, D. H. M. U., Eskes, H., Boersma, K. F., Van Roozendael, M., De Smedt, I., and Kelder, H. M.: Detection of the trend and seasonal variation in tropospheric $\mathrm{NO}_{2}$ over China, J. Geophys. Res.-Atmos., 111, D12317, doi:10.1029/2005JD006594, 2006.

van $\operatorname{der}$ A, R. J., Eskes, H. J., Boersma, K. F., van Noije, T. P. C., Van Roozendael, M., De Smedt, I., Peters, D. H. M. U., and Meijer, E. W.: Trends, seasonal variability and dominant $\mathrm{NO}_{x}$ source derived from a ten year record of $\mathrm{NO}_{2}$ measured from space, J. Geophys. Res.-Atmos., 113, D04302, doi:10.1029/2007JD009021, 2008.

Wang, S. and Hao, J.: Air quality management in China: Issues, challenges, and options, J. Environ. Sci., 24, 2-13, doi:10.1016/S1001-0742(11)60724-9, 2012.

Wang, S. W., Zhang, Q., Streets, D. G., He, K. B., Martin, R. V., Lamsal, L. N., Chen, D., Lei, Y., and Lu, Z.: Growth in $\mathrm{NO}_{x}$ emissions from power plants in China: bottom-up estimates and satellite observations, Atmos. Chem. Phys., 12, 4429-4447, doi:10.5194/acp-12-4429-2012, 2012.
Wang, Y., McElroy, M. B., Boersma, K. F., Eskes, H. J., and Veefkind, J. P.: Traffic restrictions associated with the SinoAfrican summit: Reductions of $\mathrm{NO}_{x}$ detected from space, Geophys. Res. Lett., 34, L08814, doi:10.1029/2007GL029326, 2007a.

Wang, Y., McElroy, M. B., Martin, R. V., Streets, D. G., Zhang, Q., and Fu, T.-M.: Seasonal variability of $\mathrm{NO}_{x}$ emissions over east China constrained by satellite observations: Implications for combustion and microbial sources, J. Geophys. Res.-Atmos., 112, D06301, doi:10.1029/2006JD007538, 2007b.

Wang, Y., Hao, J., McElroy, M. B., Munger, J. W., Ma, H., Chen, D., and Nielsen, C. P.: Ozone air quality during the 2008 Beijing Olympics: effectiveness of emission restrictions, Atmos. Chem. Phys., 9, 5237-5251, doi:10.5194/acp-9-5237-2009, 2009.

Witte, J. C., Schoeberl, M. R., Douglass, A. R., Gleason, J. F., Krotkov, N. A., Gille, J. C., Pickering, K. E., and Livesey, N.: Satellite observations of changes in air quality during the 2008 Beijing Olympics and Paralympics, Geophys. Res. Lett., 36, L17803, doi:10.1029/2009GL039236, 2009.

Xu, Y., Yang, C.-J., and Xuan, X.: Engineering and optimization approaches to enhance the thermal efficiency of coal electricity generation in China, Energ. Policy, 60, 356-363, doi:10.1016/j.enpol.2013.05.047, 2013.

Zhang, Q., Streets, D. G., He, K., Wang, Y., Richter, A., Burrows, J. P., Uno, I., Jang, C. J., Chen, D., Yao, Z., and Lei, Y.: NO $x$ emission trends for China, 1995-2004: The view from the ground and the view from space, J. Geophys. Res.-Atmos., 112, D22306, doi:10.1029/2007JD008684, 2007.

Zhang, Q., Streets, D. G., Carmichael, G. R., He, K. B., Huo, H., Kannari, A., Klimont, Z., Park, I. S., Reddy, S., Fu, J. S., Chen, D., Duan, L., Lei, Y., Wang, L. T., and Yao, Z. L.: Asian emissions in 2006 for the NASA INTEX-B mission, Atmos. Chem. Phys., 9, 5131-5153, doi:10.5194/acp-9-5131-2009, 2009a.

Zhang, Q., Streets, D. G., and He, K.: Satellite observations of recent power plant construction in Inner Mongolia, China, Geophys. Res. Lett., 36, L15809, doi:10.1029/2009GL038984, 2009b.

Zhang, Q., Geng, G., Wang, S., Richter, A., and He, K.: Satellite remote sensing of changes in $\mathrm{NO}_{x}$ emissions over China during 1996-2010, Chinese Sci. Bull., 57, 2857-2864, doi:10.1007/s11434-012-5015-4, 2012.

Zhang, X., Zhang, P., Zhang, Y., Li, X., and Qiu, H.: The trend, seasonal cycle, and sources of tropospheric $\mathrm{NO}_{2}$ over China during 1997-2006 based on satellite measurement, Sci. China Ser. D, 50, 1877-1884, doi:10.1007/s11430-007-0141-6, 2007.

Zhao, B., Wang, S. X., Liu, H., Xu, J. Y., Fu, K., Klimont, Z., Hao, J. M., He, K. B., Cofala, J., and Amann, M.: $\mathrm{NO}_{x}$ emissions in China: historical trends and future perspectives, Atmos. Chem. Phys., 13, 9869-9897, doi:10.5194/acp-13-9869-2013, 2013.

Zhao, C. and Wang, Y.: Assimilated inversion of $\mathrm{NO}_{x}$ emissions over east Asia using $\mathrm{OMI} \mathrm{NO} 2$ column measurements, Geophys. Res. Lett., 36, L06805, doi:10.1029/2008GL037123, 2009.

Zhao, H. Y., Zhang, Q., Guan, D. B., Davis, S. J., Liu, Z., Huo, H., Lin, J. T., Liu, W. D., and He, K. B.: Assessment of China's virtual air pollution transport embodied in trade by using a consumption-based emission inventory, Atmos. Chem. Phys., 15, 5443-5456, doi:10.5194/acp-15-5443-2015, 2015. 